Original article

\title{
Influence of the proximity of American foulbrood cases and apicultural management on the prevalence of Paenibacillus larvae spores in Belgian honey
}

\author{
Dirk C. DE GRAAF ${ }^{\mathrm{a} *}$, Dominique VANDEKERChOVE ${ }^{\mathrm{a}}$, \\ Wim Dobbelaere ${ }^{\mathrm{a}, \mathrm{b}}$, Johan E. PeEters ${ }^{\mathrm{a}}$, Frans J. JACOBS ${ }^{\mathrm{b}}$ \\ a Veterinary and Agrochemical Research Centre (VAR), Groeselenberg 99, \\ 1180 Brussels, Belgium \\ ${ }^{b}$ University of Ghent, Laboratory of Zoophysiology, Krijgslaan 281 S33, \\ 9000 Ghent, Belgium
}

(Received 21 May 2001; revised 28 August 2001; accepted 12 September 2001)

\begin{abstract}
A survey based on the bacteriological analysis of 1328 honey samples from the harvest in the summer of 1999 yielded 146 samples contaminated with $P$. larvae spores (11.0\%), ranging from the detection of only a single colony of $P$. larvae to completely overgrown plates. Risk factor analysis by logistic regression modelling revealed that honey samples collected in the proximity of apiaries with AFB cases from 1998 were at 3-times higher risk of being contaminated compared to other geographic locations (odds ratio $=3.04 ; P<0.001$ ). Comb replacement was found to lower the risk (odds ratio $=0.46 ; P=0.033$ ) and should be encouraged in beekeeping management. There was also a relation between the positive honey samples collected in 1999 and the cases of AFB in the year 2000 (odds ratio $=2.64 ; P=0.009$ ), supporting the value of honey analysis for sanitary control of bee colonies.
\end{abstract}

Paenibacillus larvae larvae / American foulbrood / honey / risk factor analysis / prevalence

\section{INTRODUCTION}

American foulbrood (AFB) is a lethal disease of the larvae of the honeybee, Apis mellifera $\mathrm{L}$. It is caused by the spore-forming, rod-shaped bacterium, Paenibacillus larvae larvae. Transmission occurs by oral uptake of the spores only, as the vegetative stages are efficiently killed in the secretions of the hypopharyngeal glands of the nursing adult worker bees (Bailey and Ball, 1991).

* Correspondence and reprints

E-mail: dideg@ var.fgov.be 
AFB is of significant economic importance in many countries throughout the world. However, this disease was considered to be sporadic in Belgium with only 23 cases from 1997 to 1999 among approximately 10000 beekeepers (= total number of memberships in Belgian beekeeper societies). Nevertheless, with the finding in 1999 of spores in honey samples from bee colonies that showed no clinical signs of the disease, the apparently low prevalence of AFB in Belgium had to be called into question.

Therefore, a survey was conducted based on bacteriological analysis of honey samples. Since Hansen (1984) demonstrated that $P$. larvae spores can easily be recovered from honey, this technique has been applied worldwide for the estimation of the prevalence of AFB (Shimanuki and Knox, 1988; Hornitzky and Clark, 1991; Ritter, 1992; Steinkraus and Morse, 1992). The unique situation in Belgium, with only a very limited number of cases each year (and most of those in the north) and with areas where no AFB was found in the past decade or even longer, enabled us to assess the influence of the proximity of AFB cases on the contamination of honey samples. All participating beekeepers were asked to complete a questionnaire about their beekeeping management practices for a risk factor analysis.

\section{MATERIALS AND METHODS}

\subsection{Collection of samples and management characteristics}

The study was conducted anonymously throughout Belgium, with the postal code of the area where the apiary was located as the only geographic reference. The different Belgian beekeeper societies acted as intermediaries for the collection of the samples. Each society received numbered specimen cups with caps for honey sampling (from the harvest of summer 1999; one honey sample per apiary), together with the corresponding numbered questionnaires designed to gather basic information about the technical management of the apiary. Upon arrival at the Veterinary and Agrochemical Research Centre (VAR), honey samples were stored at $4{ }^{\circ} \mathrm{C}$ until analysis.

\subsection{Bacteriological testing}

The method from Hornizky and Clark (1991) for isolation of P. larvae spores from honey was adapted for small samples. In short, $5 \mathrm{~g}$ honey was mixed in a Falcon ${ }^{\circledR}$ $50 \mathrm{ml}$-tube with an equal volume of sterile phosphate buffered saline $\mathrm{pH} 7.2$ (PBS) and placed in a water bath at $50{ }^{\circ} \mathrm{C}$ for $15 \mathrm{~min}$. The mixture was vigorously shaken and afterwards centrifuged at room temperature for $30 \mathrm{~min}$ at $4000 \mathrm{~g}$. The supernatant was removed and the pellet possibly containing P. larvae spores was resuspended in $200 \mu \mathrm{l}$ sterile PBS. Vegetative stages of $P$. larvae or contaminating temperature-sensitive bacteria were killed by heat-shock $\left(80^{\circ} \mathrm{C}\right.$, $15 \mathrm{~min}$ ). The samples were then streaked on selective MYPGP agar (Dingman and Stahly, 1983) containing nalidixic acid $\left(9 \mu \mathrm{g} \cdot \mathrm{mL}^{-1}\right)$ and pipemidic acid $\left(20 \mu \mathrm{g} \cdot \mathrm{mL}^{-1}\right)$ (Alippi, 1995). Plates were incubated at $37{ }^{\circ} \mathrm{C}$ for 4 days. The first day we counted the number of colonies of contaminating fast-growing bacteria. The 4th day we counted the number of colonies with the typical $P$. larvae morphology: small, flat, round colonies, grey-whitish in colour with a regular, hazy border. Sterility of the solutions and of the manipulations was verified through inclusion of an autoclaved, and therefore guaranteed negative honey sample, for every 15 bacteriological analyses performed.

At least one colony of each suspicious sample was subcultured for further identification. Bacteria were identified as P. larvae if they were Gram-positive rods, catalase negative, with a positive $16 \mathrm{~S}$ rRNA gene PCR reaction (Govan et al., 1999). For the 
latter, template DNA was prepared as follows: a colony was mixed with $50 \mu \mathrm{l}$ MilliQ water and heat-treated $\left(95^{\circ} \mathrm{C}, 15 \mathrm{~min}\right)$, after which debris was removed by centrifugation (13000 $g$ for $5 \mathrm{~min}$ ). The PCR reaction was as described by Dobbelaere et al. (2001) using the HotStarTaq ${ }^{\mathrm{TM}}$ DNA polymerase kit (Qiagen) and the unique forward and reverse $P$. larvae primers found by Govan and colleagues (Govan et al., 1999). The reaction was positive if a 983-bp PCR amplicon could be visualized on a $0.8 \%$ agarose, $0.5 \mu \mathrm{g} / \mathrm{ml}$ ethidium bromide gel.

All P. larvae isolates were further cultured in $5 \mathrm{ml}$ Luria Bertani broth (Sambrook et al., 1989) at $37{ }^{\circ} \mathrm{C}$ for 4 days in order to make $25 \%$ glycerol stocks, to be kept at $-80{ }^{\circ} \mathrm{C}$

\subsection{Outbreak areas}

To assess the influence of the proximity of AFB cases on occurrence of P. larvae spores in honey, we defined an outbreak area (OA). An OA is the group of postal code areas situated completely or partially within a radius of $5 \mathrm{~km}$ around the centre of a postal code area with a confirmed case of AFB in the period from 1997 to 1999. Depending on the presence or absence of clinical signs in the AFB case, we defined clinical and subclinical OAs. In this way, the clinical OAs of 1997, 1998 and 1999, and the subclinical OAs of 1999 were outlined. Per year, often more than one AFB case was reported within the same or neighbouring postal code areas. To study the cumulative effect of subsequent cases, we also took into account the number of times a certain postal code area fell within an OA in a certain year $(=$ frequency inside $\mathrm{OA}$; see Fig. 1).

\subsection{Univariate logistic regression}

In a first univariate logistic regression analysis (SPSS, 1998), "isolation of P. lar$v a e$ " in honey was used as the dependent variable. The results were interpreted in 3 different ways according to the number of $P$. larvae colonies isolated: (1) presence or absence of $P$. larvae, (2) presence of more or less than 10 colonies (if less than 10 colonies were isolated the sample was considered negative) and (3) presence of more or less than 50 colonies (if less than 50 colonies were isolated the sample was considered negative). The following independent variables were categorical: inside clinical OA 1997, inside clinical OA 1998, inside OA 1999, details OA 1999, bee breed, introduction of swarms ( $5 \mathrm{y}=$ in the past 5 years $)$, introduction of external brood (5y), introduction of a new queen $(1 \mathrm{y}=$ in the past year), travelling with the beehives (1y), severe concurrent Nosema infection (1y), severe concurrent Varroa infestation

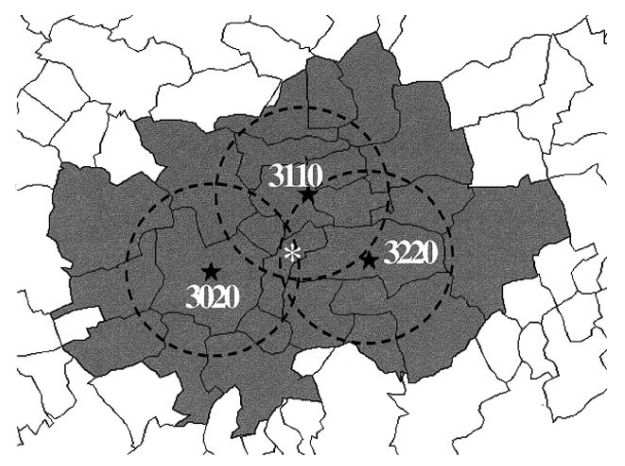

Figure 1. Three overlapping clinical Outbreak Areas (OA) of 1998. The postal code areas situated completely or partially within the $5 \mathrm{~km}$ radius (dotted line) are grey. The OAs were used to compare the influence of the proximity of an AFB case on the prevalence of $P$. larvae spores in the honey. The cumulative effect of subsequent cases in a certain year in the same or neighbouring geographic locations was analysed by counting the number of times a postal code area was marked as being inside an OA. In 1998 for example, in the postal code area-3020 two clinical AFB cases were found, and in the zones 3110 and 3220 only one. In this case, the postal code area lying at the section of the three OAs, marked with an asterisk, had a frequency of 4 (twice in OA-3020, and once in OA-3110 and OA-3220). 
(1y), concurrent Acarapis infestation (1y), use of second-hand bee hives and frames $(5 y)$, feeding of honey ( $5 y)$, feeding of pollen $(5 y)$, comb replacement $(5 y)$, and common use of equipment. Comb replacement was defined as the replacement of old combs by new foundation that was purchased elsewhere. As this question was meant to estimate the risk of introducing external wax into the apiary, we excluded comb replacement by home-made foundation. The remaining independent variables were continuous, i.e. number of bee colonies in the apiary, and the number of times a postal code area was marked as being situated in an OA (= frequency inside OA). In addition, univariate logistic regression was performed using the AFB cases of 2000 (the year following the honey sampling) as a dependent variable. In this analysis, the independent variable was "isolation of $P$. larvae", categorized in the same way as described above.

\subsection{Multifactorial logistic regression}

Only the risk factors that were significant, or that tended toward significance (i.e. $P<0.08)$ in univariate logistic regression were used in a multi factorial logistic regression without interaction terms. In so doing, the expected cell frequency was more than 5, a requirement for the chi-square statistic which was not met in the multifactorial logistic regression with all studied variables. A final model was established using the backward stepwise modelling procedure.

In Tables II, III and IV the output of two statistical tests are given: the model chisquare and the Wald statistic. The goodness of fit chi-square is an overall statistic which does not assure that every independent variable is significant. The Wald statistic tests the significance of the logit coefficient associated with a given independent variable. It is the ratio of the unstandardized logit coefficient to its standard error. The logit coefficient can be converted easily into a statement about odds ratio (OR) of the dependent variable simply by using the exponential function. The $P$-values of the Wald statistic and the OR are given. More information about logistic regression can be found on the World Wide Web (http:// www2.chass.ncsu.edu/garson/pa765/logistic.htm)

\section{RESULTS}

Approximately $13 \%$ of the Belgian beekeepers responded to the survey. From the 1328 collected honey samples, 146 were found to contain P. larvae spores (11.0\%), ranging from the detection of only a single colony of $P$. larvae to completely overgrown plates. $90.1 \%$ of the samples were contaminated by other fast-growing bacteria. More details of the bacteriological analysis and the processing of the questionnaires can be found in Table I. The data are provided as total figures for the whole of Belgium and per province. This survey was not designed for mutual comparison of the provinces, nevertheless, some remarkable observations were noticed: (1) the northern provinces (WestVlaanderen, Oost-Vlaanderen, Antwerpen, Limburg and Brabant) had higher prevalences than the southern provinces Liège and Namur; (2) in the northern provinces, most of the participating beekeepers keep bees derived from A. m. carnica whereas in the south there are many apiaries with bees derived more from A. m. mellifera; (3) in the south, beekeepers rarely introduce external brood into the apiary, and they hardly ever travel with their bees, and (4) many beekeepers feed their bees with honey.

Risk factor analyses of the proximity of AFB cases and the apicultural management by univariate logistic regression analysis are summarized in Table II. When the dependent variable was categorized as being positive for "number $P$. larvae found per $5 \mathrm{~g}$ honey" ( $P$. larvae $>0)$, two independent variables were highly significant: "inside clinical OA 1998" and "frequency inside 
Table I. Descriptive statistics: bacteriological and beekeeping technical information.

\begin{tabular}{|c|c|c|c|c|c|c|c|c|c|c|}
\hline & Belgium & $\begin{array}{c}\text { West- } \\
\text { Vlaanderen }\end{array}$ & $\begin{array}{c}\text { Oost- } \\
\text { Vlaanderen }\end{array}$ & Antwerpen & Limburg & Brabant $^{\infty}$ & Hainaut & Liège & Namur & Luxembourg $\S$ \\
\hline Honey samples ${ }^{1}$ & 1328 & 66 & 178 & 353 & 317 & 228 & 28 & 81 & 69 & 8 \\
\hline \# P. larvae $>0(\text { per } 5 \mathrm{~g} \text { honey })^{2}$ & 11.0 & 16.7 & 10.1 & 13.6 & 8.5 & 15.4 & 14.3 & 0.0 & 4.3 & 0.0 \\
\hline $0<\#$ P. larvae $<11$ (per $5 \mathrm{~g}$ honey) ${ }^{2}$ & 5.3 & 4.5 & 3.4 & 7.4 & 4.1 & 9.2 & 3.6 & 0.0 & 1.4 & 0.0 \\
\hline $10<\#$ P. larvae $<51(\text { per } 5 \mathrm{~g} \text { honey })^{2}$ & 2.3 & 4.5 & 1.1 & 3.1 & 1.6 & 3.5 & 7.1 & 0.0 & 0.0 & 0.0 \\
\hline \# P. larvae $>50$ (per $5 \mathrm{~g}$ honey $)^{2}$ & 3.3 & 7.6 & 5.6 & 3.1 & 2.8 & 2.6 & 3.6 & 0.0 & 2.9 & 0.0 \\
\hline Undefined bee breed $^{2}$ & 23.9 & 33.3 & 41.0 & 21.0 & 8.8 & 33.3 & 21.4 & 25.9 & 21.7 & 37.5 \\
\hline Derived from Apis mellifera mellifera ${ }^{2}$ & 7.8 & 3.0 & 1.7 & 0.0 & 0.3 & 11.4 & 75.0 & 17.3 & 47.8 & 37.5 \\
\hline Derived from Apis mellifera carnica ${ }^{2}$ & 57.2 & 60.6 & 53.4 & 68.8 & 78.5 & 40.4 & 0.0 & 43.2 & 4.3 & 25.0 \\
\hline Derived from Apis mellifera ligustica ${ }^{2}$ & 0.1 & 0.0 & 0.0 & 0.0 & 0.3 & 0.0 & 0.0 & 0.0 & 0.0 & 0.0 \\
\hline Buckfast $^{2}$ & 11.1 & 3.0 & 3.9 & 10.2 & 12.0 & 14.9 & 3.6 & 13.6 & 26.1 & 0.0 \\
\hline Number of bee colonies on the apiary ${ }^{3}$ & 9.5 & 8.5 & 9.2 & 9.6 & 10.4 & 8.4 & 7.2 & 10.8 & 10.0 & 8.1 \\
\hline Introduction of swarms ${ }^{2}$ & 59.0 & 75.8 & 70.2 & 54.7 & 46.4 & 63.2 & 71.4 & 58.0 & 79.7 & 25.0 \\
\hline Introduction of external brood $^{2}$ & 10.0 & 13.6 & 15.2 & 11.3 & 7.6 & 11.0 & 3.6 & 4.9 & 4.3 & 0.0 \\
\hline Introduction of new queen ${ }^{2}$ & 34.8 & 27.3 & 32.0 & 32.0 & 45.4 & 35.1 & 21.4 & 32.1 & 26.1 & 0.0 \\
\hline Travelling with beehives ${ }^{2}$ & 39.0 & 31.8 & 27.0 & 59.8 & 54.9 & 21.1 & 0.0 & 7.4 & 13.0 & 12.5 \\
\hline Severe intercurrent Nosema-infection ${ }^{2}$ & 2.5 & 1.5 & 9.0 & 2.3 & 1.3 & 1.3 & 0.0 & 1.2 & 0.0 & 0.0 \\
\hline Severe intercurrent Varroa-infestation ${ }^{2}$ & 13.3 & 7.6 & 18.5 & 7.6 & 18.9 & 9.6 & 7.1 & 8.6 & 29.0 & 0.0 \\
\hline Intercurrent Acarapis-infestation ${ }^{2}$ & 0.2 & 0.0 & 0.0 & 0.0 & 0.6 & 0.0 & 0.0 & 0.0 & 0.0 & 0.0 \\
\hline Use of second-hand beehives and frames ${ }^{2}$ & 11.9 & 16.7 & 17.4 & 11.0 & 10.1 & 11.8 & 10.7 & 8.6 & 10.1 & 12.5 \\
\hline Feeding of honey ${ }^{2}$ & 28.7 & 25.8 & 21.3 & 26.1 & 27.4 & 25.9 & 21.4 & 45.7 & 59.4 & 50.0 \\
\hline Feeding of pollen ${ }^{2}$ & 3.3 & 3.0 & 1.1 & 1.1 & 4.4 & 1.8 & 3.6 & 17.3 & 2.9 & 12.5 \\
\hline Comb replacement ${ }^{2}$ & 81.4 & 81.8 & 87.6 & 78.8 & 77.0 & 85.1 & 71.4 & 85.2 & 85.5 & 87.5 \\
\hline Common use of equipment ${ }^{2}$ & 12.4 & 15.2 & 4.5 & 19.5 & 12.3 & 9.6 & 10.7 & 2.5 & 15.9 & 12.5 \\
\hline
\end{tabular}

${ }^{1}$ Sample size.

2 Percentage.

${ }^{3}$ Average.

${ }_{\infty}^{\infty}$ Province Vlaams-Brabant, province Brabant-Wallon and capital Brussels (= ancient province Brabant).

$\S$ Belgian province Luxembourg (not the Grand Duchy of Luxembourg). 
Table II. Risk factor analyses through univariate logistic regression based on the geographic distribution of AFB cases and on apicutural management.

\begin{tabular}{|c|c|c|c|c|c|c|c|c|c|}
\hline \multirow[t]{4}{*}{ Independent variables / reference categories } & \multicolumn{9}{|c|}{$\begin{array}{l}\text { Dependent variables } \\
\text { Number of } P \text {. larvae/5 } \mathrm{g} \text { honey }\end{array}$} \\
\hline & \multicolumn{3}{|c|}{$>0$} & \multicolumn{3}{|c|}{$>10$} & \multicolumn{3}{|c|}{$>50$} \\
\hline & \multicolumn{2}{|c|}{$P$ value } & \multirow[t]{2}{*}{$\mathrm{OR}^{\S}$} & \multicolumn{2}{|c|}{$P$ value } & \multirow[t]{2}{*}{$\mathrm{OR}^{\S}$} & \multicolumn{2}{|c|}{$P$ value } & \multirow[t]{2}{*}{$\mathrm{OR}^{\S}$} \\
\hline & $\mathrm{Chi}^{2}$ & Wald & & $\mathrm{Chi}^{2}$ & Wald & & $\mathrm{Chi}^{2}$ & Wald & \\
\hline Inside clinical OA 1997 / outside & 0.28 & 0.26 & 1.52 & 0.68 & 0.67 & 1.25 & 0.45 & 0.42 & 1.63 \\
\hline Inside clinical OA 1998 / outside & $0.001^{*}$ & $<0.001^{*}$ & 3.04 & $0.078^{(*)}$ & $0.055^{(*)}$ & 2.24 & 0.52 & 0.50 & 1.52 \\
\hline Inside OA 1999 / outside & 0.69 & 0.69 & 0.91 & 0.28 & 0.26 & 0.72 & 0.32 & 0.34 & 1.58 \\
\hline Details OA 1999 / outside & 0.48 & 0.47 & & 0.50 & 0.43 & & 0.24 & 0.92 & \\
\hline Inside subclinical OA 1999 only / outside & & 0.27 & 1.51 & & 0.12 & 2.03 & & 0.97 & 0.97 \\
\hline Inside clinical OA 1999 only / outside & & 0.44 & 0.77 & & 0.91 & 0.95 & & 0.58 & 0.71 \\
\hline Inside both subclinical and clinical OA 1999 / outside & & 0.42 & 1.37 & & 0.57 & 1.35 & & 0.66 & 0.003 \\
\hline Frequency inside clinical OA 1997 / continuous: n.a. & 0.28 & 0.26 & 1.52 & 0.68 & 0.67 & 1.25 & 0.45 & 0.42 & 1.63 \\
\hline Frequency inside clinical OA 1998 / continuous: n.a. & $0.004^{*}$ & $0.002^{*}$ & 1.48 & 0.17 & 0.14 & 1.30 & 0.90 & 0.90 & 0.96 \\
\hline Frequency inside OA 1999 / continuous: n.a. & 0.61 & 0.60 & 1.06 & 0.50 & 0.49 & 1.11 & 0.08 & 0.15 & 0.58 \\
\hline Frequency inside subclinical OA 1999 only / continuous: n.a. & 0.43 & 0.41 & 1.15 & 0.29 & 0.26 & 1.27 & 0.15 & 0.25 & 0.50 \\
\hline Frequency inside clinical OA 1999 only / continuous: n.a & 0.96 & 0.96 & 0.99 & 0.90 & 0.90 & 0.96 & 0.15 & 0.20 & 0.47 \\
\hline Frequency inside both subclinical and clinical OA 1999 / continuous: n.a. & 0.58 & 0.57 & 1.08 & 0.56 & 0.54 & 1.11 & $0.047^{*}$ & 0.65 & 0.12 \\
\hline Bee breed / undefined bee breed & 0.43 & 0.56 & & 0.52 & 0.56 & & 0.90 & 0.93 & \\
\hline Derived from A. m. mellifera / undefined bee breed & & 0.10 & 0.47 & & 0.82 & 0.88 & & 0.45 & 0.55 \\
\hline Derived from A. m. carnica / undefined bee breed & & 0.89 & 0.97 & & 0.17 & 1.53 & & 0.89 & 0.95 \\
\hline Derived from A. $m$. ligustica / undefined bee breed & & 0.81 & 0.04 & & 0.89 & 0.04 & & 0.90 & 0.06 \\
\hline Buckfast / undefined bee breed & & 0.98 & 0.99 & & 0.86 & 1.09 & & 0.74 & 1.19 \\
\hline
\end{tabular}


Table II. (Continued).

\begin{tabular}{|c|c|c|c|c|c|c|c|c|c|}
\hline \multirow[t]{4}{*}{ Independent variables / reference categories } & \multicolumn{9}{|c|}{$\begin{array}{c}\text { Dependent variables } \\
\text { Number of } P \text {. larvae/5 } \mathrm{g} \text { honey }\end{array}$} \\
\hline & \multicolumn{3}{|c|}{$>0$} & \multicolumn{3}{|c|}{$>10$} & \multicolumn{3}{|c|}{$>50$} \\
\hline & \multicolumn{2}{|c|}{$P$ value } & \multirow[t]{2}{*}{$\mathrm{OR}^{\S}$} & \multicolumn{2}{|c|}{$P$ value } & \multirow[t]{2}{*}{$\mathrm{OR}^{\S}$} & \multicolumn{2}{|c|}{$P$ value } & \multirow[t]{2}{*}{$\mathrm{OR}^{\S}$} \\
\hline & $\mathrm{Chi}^{2}$ & Wald & & $\mathrm{Chi}^{2}$ & Wald & & $\mathrm{Chi}^{2}$ & Wald & \\
\hline Number of bee colonies in the apiary / continuous: n.a. & 0.14 & 0.16 & 0.98 & $0.046^{*}$ & $0.068^{(*)}$ & 0.96 & $0.051^{(*)}$ & 0.08 & 0.95 \\
\hline Introduction of swarms / no & 0.71 & 0.71 & 1.07 & 0.65 & 0.65 & 1.12 & 0.13 & 0.13 & 0.63 \\
\hline Introduction of external brood / no & 0.91 & 0.91 & 0.03 & 0.85 & 0.85 & 1.08 & 0.83 & 0.83 & 0.89 \\
\hline Introduction of new queen / no & 0.20 & 0.20 & 0.79 & 0.78 & 0.79 & 0.93 & 0.67 & 0.67 & 0.87 \\
\hline Travelling with beehives / no & 0.21 & 0.21 & 1.25 & 0.67 & 0.67 & 1.11 & 0.71 & 0.72 & 0.89 \\
\hline Severe concurrent Nosema-infection / no & 0.72 & 0.72 & 0.81 & 0.92 & 0.92 & 1.08 & 0.14 & 0.64 & 0.01 \\
\hline Severe concurrent Varroa-infestation / no & 0.50 & 0.49 & 1.18 & 0.48 & 0.50 & 0.77 & $0.050^{*}$ & 0.10 & 0.30 \\
\hline Concurrent Acarapis-infestation / no & 0.51 & 0.74 & 0.04 & 0.64 & 0.83 & 0.03 & 0.72 & 0.86 & 0.06 \\
\hline Use of second-hand beehives and frames / no & 0.87 & 0.86 & 1.05 & 0.26 & 0.29 & 0.63 & 0.54 & 0.56 & 0.73 \\
\hline Feeding of honey / no & 0.34 & 0.34 & 0.83 & 0.70 & 0.70 & 1.11 & 0.90 & 0.90 & 1.04 \\
\hline Feeding of pollen / no & 0.94 & 0.94 & 1.04 & 0.74 & 0.73 & 1.23 & 0.24 & 0.20 & 2.22 \\
\hline Comb replacement / no & 0.53 & 0.52 & 0.87 & 0.23 & 0.22 & 0.71 & $0.074^{(*)}$ & $0.062^{(*)}$ & 0.53 \\
\hline Common use of equipment / no & 0.15 & 0.17 & 0.66 & 0.21 & 0.24 & 0.60 & 0.22 & 0.26 & 0.51 \\
\hline
\end{tabular}

$\S \mathrm{OR}$, odds ratio.

(*) Tendency to significance $(0.080>P>0.050)$.

(*) Tendency to significa 
clinical OA 1998". Since these two variables were strongly correlated (Pearson correlation $0.897 ; P<0.001$ ), only one of them could be used in the logistic regression model, and a multifactorial analysis could not be performed. When the dependent variable was the presence/absence of $P$. larvae based on the number of colonies $>10$ or $>50$, the number of significant or borderline significant risk factors was 2 and 4 respectively. In the multifactorial analysis of the first set risk factors ( . larvae $>10)$, rejection of the variable "inside clinical OA 1998" by the backward stepwise modelling procedure provided the best model $(P=0.048)$ and an OR of 0.96 for "number of bee colonies in the apiary" (borderline significant Wald statistic; see Tab. III). For the second set of risk factors $(P$. larvae $>50)$ the model was highly significant $(P=0.009)$ without rejection of any of the 4 variables. However, only "comb replacement" gave a significant Wald statistic with an OR of 0.46.

There was a significant relation between the 1999 honey samples with a positive $P$. larvae analysis (P. larvae $>0$ and $>10)$ and the cases of AFB in the year 2000 (odds ratios 2.64 and 3.58 respectively; see Tab. IV).

\section{DISCUSSION}

Since Hansen (1984) introduced the screening of honey for the occurrence of $P$. larvae spores, many other studies have used the same method (Shimanuki and Knox, 1988; Hornitzky and Clark, 1991; Ritter, 1992; Steinkraus and Morse, 1992; Alippi, 1995). Ours is the first study to combine comprehensive honey sampling to give unambiguous identification of the species P. larvae by PCR, with a risk factor analysis run in parallel with the bacteriological survey. Because of the lack of an obliged registration of beekeepers in Belgium, the samples used in this study were not randomly collected, but were based on a voluntary participation, which may have caused a certain bias in the results. Nevertheless, approximately $13 \%$ of the Belgian beekeepers responded, which allowed us to draw some careful conclusions.

Taking into account that in the past decades no more than 9 clinical AFB cases could be found per year in Belgium, the presence of $P$. larvae in $11 \%$ of the honey samples was unexpectedly high. These findings confirm earlier findings of Hansen and Rasmussen (1986) that the presence of

Table III. Risk factor analyses through multifactorial logistic regression.

\begin{tabular}{|c|c|c|c|c|c|c|}
\hline \multirow[t]{4}{*}{ Independent variables } & \multicolumn{6}{|c|}{$\begin{array}{l}\text { Dependent variables } \\
\text { Number of } P \text {. larvae/5 g honey }\end{array}$} \\
\hline & \multicolumn{3}{|c|}{$>10$} & \multicolumn{3}{|c|}{$>50$} \\
\hline & \multicolumn{2}{|c|}{$P$ value } & \multirow[t]{2}{*}{$\mathrm{OR}^{\S}$} & \multicolumn{2}{|c|}{$P$ value } & \multirow[t]{2}{*}{$\mathrm{OR}^{\S}$} \\
\hline & $\mathrm{Chi}^{2}$ & Wald & & $\mathrm{Chi}^{2}$ & Wald & \\
\hline Frequency inside both subclinical and clinical OA 1999 & & & & $0.009^{*}$ & 0.65 & 0.12 \\
\hline Number of bee colonies on the apiary & \multirow{3}{*}{\multicolumn{2}{|c|}{$0.048^{*} 0.069^{(*)}$}} & \multirow[t]{3}{*}{0.96} & & 0.13 & 0.96 \\
\hline Severe concurrent Varroa-infestation & & & & & 0.15 & 0.35 \\
\hline Comb replacement & & & & & $0.033^{*}$ & 0.46 \\
\hline
\end{tabular}

$\S$ OR, odds ratio.

* Significant $(P<0.05)$

(*) Tendency to significance $(0.080>P>0.050)$. 
Table IV. Relation between presence of P. larvae in honey samples from 1999 and the AFB cases of 2000 .

\begin{tabular}{llll}
\hline Independent variables & \multicolumn{3}{c}{$\begin{array}{c}\text { Dependent variables } \\
\text { AFB cases of 2000 }\end{array}$} \\
\cline { 2 - 3 } & \multicolumn{2}{c}{$P$ value } & $\mathrm{OR}^{\S}$ \\
\cline { 2 - 3 } & $\mathrm{Chi}^{2}$ & Wald & \\
\hline Number of $P$. larvae/5 g honey $>0$ & $0.017^{*}$ & $0.009^{*}$ & 2.64 \\
Number of $P$. larvae/5 g honey $>10$ & $0.009^{*}$ & $0.003^{*}$ & 3.58 \\
Number of $P$. larvae/5 g honey $>50$ & 0.22 & 0.17 & \\
\hline
\end{tabular}

$\S$ OR, odds ratio.

* Significant $(P<0.05)$.

P. larvae in an apiary does not necessarily mean that the larvae become clinically ill. There might be several reasons for this: (1) clinical disease requires a minimum $P$. larvae contamination level; (2) not all P. larvae strains are equally virulent; and (3) some bee populations may have developed tolerance to the disease. Most likely a combination of these factors determines whether clinical disease occurs or not. Hansen and Rasmussen (1986) found substantial differences in numbers of $P$. larvae spores present, before AFB was triggered, indicating that other parameters were involved.

Differences in virulence between $P$. larvae strains have been poorly studied. So far, only two pathotypes of $P$. larvae have been clearly described, Paenibacillus larvae larvae and Paenibacillus larvae pulvifaciens. These are distinguished at the subspecies level (Heyndrickx et al., 1996), the former causing the more common AFB, with gluelike consistency of the infected larvae and the latter associated with a rare disease called powdery scale. Hitchcock and Wilson (1973) compared the pathogenicity of nitrate reductase positive $P$. larvae strains with those that were nitrate reductase negative. They found only minor differences in virulence between the two groups (99.1 and $94.8 \%$ of the larvae became ill, respectively), but more importantly, they found a strain from Utah, that could not evoke clinical disease because of its inability to produce sufficient numbers of spores. We believe that beside the potential to sporulate, other virulence characteristics remain to be determined. The molecular comparison of the 146 P. larvae strains isolated in this study is now ongoing.

The increased risk of finding P. larvae spores in honey from geographic locations close to AFB-infected apiaries seems logical. In general, most $P$. larvae contaminated samples were collected in the north, the region that was affected most frequently by AFB in the past 4 years (Fig. 2). The natural transmission of $P$. larvae between colonies of the same and different apiaries has long been attributed to drifting (Matheson, 1984) and robbing of bees (Hansen and Brødsgaard, 1999). However, since Goodwin et al. (1994) found only $5.7 \%$ of marked bees in the wrong bee colonies, drifting of honeybees is no longer considered to be of major importance in the spread of AFB. On the contrary, robbing is still considered important, especially when honey stocks of heavily diseased colonies are left defenceless when the colonies finally collapse, or when the bees are killed by sulphur fumigation as an eradication strategy and the hives are not destroyed or sufficiently sealed immediately afterwards. One might question why this relation between the proximity of AFB cases and $P$. larvae contaminated honey was not 
(a)

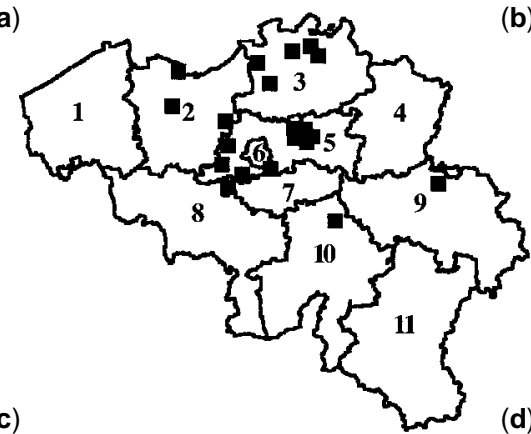

(c)

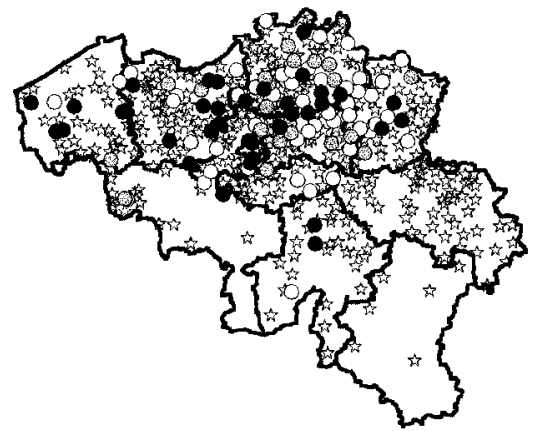

(b)
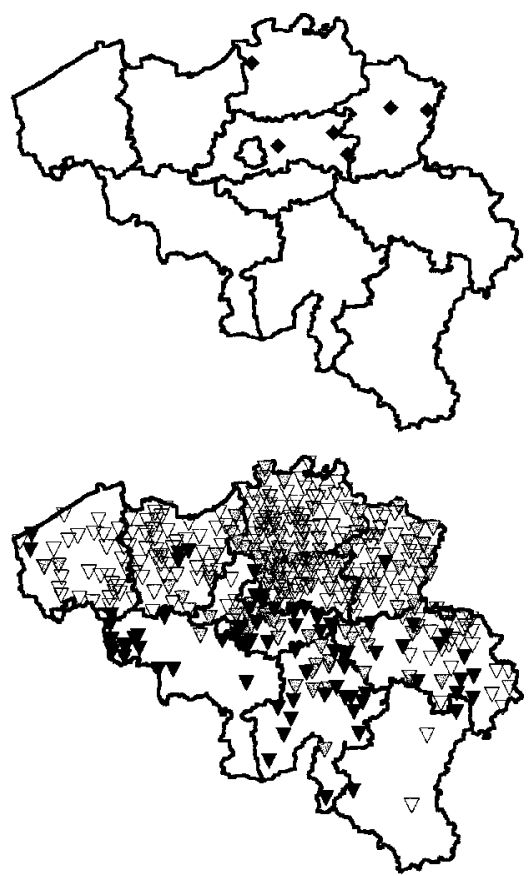

Figure 2. Geographic distribution of (a) the AFB cases from 1997-1999, (b) the AFB cases in 2000, (c) the prevalence of $P$. larvae spores in honey, and (d) the breed of honey bee. In (a) the political provinces are marked: $1=$ West-Vlaanderen, $2=$ Oost-Vlaanderen, $3=$ Antwerpen, $4=$ Limburg, $5=$ Vlaams-Brabant, $6=$ Brussels, $7=$ Brabant-Wallon, $8=$ Hainaut, $9=$ Liège, $10=$ Namur and $11=$ Luxembourg. In $(\mathbf{c})$ only the highest $P$. larvae contaminated samples were marked per postal code area (white star: negative; white bullet: $1-10$ spores/5 g honey; grey bullet: $11-50$ spores/5 g honey; black bullet: $>50$ spores/ $5 \mathrm{~g}$ honey). In (d) the 3 main bee breeds were marked (white triangle: $A$. $m$. carnica, grey triangle: Buckfast and black triangle: A. m. mellifera).

found for geographic locations where AFB was recorded in the year 1999. An explanation might be that from 1999 on, the Belgian Veterinary Service acted upon its eradication strategy against AFB more strictly, with obligatory destruction of all bees from an infected apiary and from the apiaries with subclinical disease located in the $3 \mathrm{~km}$ surveillance area around the affected apiary. This more stringent approach seemed to prevent an increased contamination level in the area surrounding the AFB cases.

The favourable influence of comb replacement is consistent with what was found many years ago for Nosema disease (Fries, 1988). Frequent comb replacement should be encouraged in apicultural management to control bee diseases by the simple removal of contaminated combs and by promoting the building of new ones by the bees. Wax can contain spores of $P$. larvae (Machova, 1993), but the risk of infecting a colony through the introduction of contaminated foundation seems minimal due to the secretion of new wax during comb building by the bees. The secretions of the wax glands can be considered spore-free and therefore, newly built combs must have a very low contamination level.

Although the number of bee colonies in the apiary was demonstrated to be related to the presence of $P$. larvae in honey samples 
by both univariate and multifactorial logistic regression analysis, the biological value of an OR of 0.96 (Wald statistic $P=0.069$ ) is negligible. Other statistical relations could not be confirmed by multifactorial analysis and should therefore be interpreted with great care.

No significant relation was observed between the occurrence of AFB and the bee breed in the apiary, but one should take into account that the reference category used (undefined bee breed) was a complex mixture of subspecies, hybrids of known strains, or bee strains that could not be named by the beekeepers. In addition, the distribution of bee strains in Belgium seems to be geographically determined which might bias the risk factor analysis. For instance, the bees derived from the $A$. $m$. mellifera subspecies were found more often in the south (Fig. 2), where apicultural management was noticed to be different (Tab. I) and where the vegetation and thus nectar flow also differ completely.

The finding that postal code areas with $P$. larvae contaminated honey samples were more often affected by AFB in the following year, supports the value of honey analyses for the sanitary control of beehives. Probably, the odds ratios would have been much better defined if we had chosen a study design in which known beekeepers were followed for subsequent years. By choosing to use an anonymous survey, we failed to have information on the contamination level of the honey samples from the same apiary the year that preceded an outbreak of AFB disease. As the postal code was the only geographic information, it was not possible to distinguish between the influence of honey contamination levels of the neighbouring apiaries within the same postal code area on the one hand, and of the same apiary on the other hand, the former being probably much less important.

This study will certainly give rise to an evaluation of the Belgian eradication strategy in its present form. It also uncovers the urgent need of scientific knowledge on the virulence of $P$. larvae strains isolated from asymptomatic beehives. Further, it demonstrates that some of the peculiarities of the beekeeping sector in Belgium with no obliged registration, and thus lack of data on density and size of apiaries, distribution of breeds and most importantly the impossibility of taking samples randomly, cause a considerable handicap in the interpretation of epidemiological data.

\section{ACKNOWLEDGEMENTS}

This work was supported by funds from the Belgian Ministry of Small Enterprises, Traders and Agriculture (Dienst Landbouwkundig Onderzoek; S-5886) and by a grand of the Flemish beekeepers federation (Koninklijke Vlaamse Imkersbond).

Résumé - Influence de la proximité de cas de loque américaine et de la gestion apicole sur la fréquence de spores de Paenibacillus larvae dans les miels belges. $\mathrm{La}$ loque américaine est une maladie mortelle pour les larves d'abeilles (Apis mellifera L.), causée par la bactérie sporulante Paenibacillus larvae larvae. La présence de spores en 1999 dans des colonies ne présentant pas de symptômes remet en question la fréquence apparemment faible de la loque américaine en Belgique. Une étude basée sur l'analyse bactériologique de 1328 échantillons de miel de la récolte de l'été 1999 a fourni 146 échantillons contaminés par les spores de $P$. larvae $(11,0 \%$; Tab. I). La contamination variait entre une seule colonie et des plaques entièrement recouvertes de colonies de $P$. larvae. Pour estimer l'influence de la proximité de cas de loque américaine sur la présence de spores de $P$. larvae dans les miels, nous avons défini une zone d'apparition (ZA) de la maladie (OA, Fig. 1). Une ZA est le regroupement des zones de codes postaux situées complètement ou partiellement dans un rayon de cinq $\mathrm{km}$ autour d'une zone de code postal centrale où un cas de 
loque américaine a été reconnu durant la période 1997-1999. L'analyse statistique par la régression logique à une variable, utilisant le logiciel SPSS version 8.0 avec comme variable dépendante « le nombre de spores de $P$. larvae trouvé dans $5 \mathrm{~g}$ de miel », a montré deux variables indépendantes hautement significatives : «à l'intérieur d'une ZA clinique de 1998 » et «la fréquence à l'intérieur d'une ZA clinique de 1998 » (Tab. II). Ainsi le risque était accru de trouver des spores de $P$. larvae dans les miels des zones géographiques proches des ruchers ayant des cas de loque américaine. Dans une analyse multifactorielle des données portant sur les pratiques de gestion apicole des ruchers correspondants, seul le facteur « remplacement du rayon » a donné une statistique de Wald significative avec un rapport des chances de 0,46 (Tab. III). Le remplacement fréquent des rayons devrait donc être encouragé dans la gestion des colonies pour lutter contre les maladies par simple retrait des rayons contaminés. Il $\mathrm{y}$ avait finalement une relation significative entre les échantillons de miel de 1999 avec une analyse positive de $P$. larvae ( $P$. larvae $>0$ et $>10$ ) et les cas de loque américaine en l'an 2000 (rapport des chances de 2,64 et 3,58 respectivement; Tab. IV). Cela montre la valeur des analyses de miel pour le contrôle sanitaire des colonies d'abeilles.

Paenibacillus larvae subsp. larvae / loque américaine / miel / facteur de risque

Zusammenfassung - Einfluss von in der Nähe auftretenden Fällen von Amerikanischer Faulbrut und von imkerlichen Eingriffen auf das Vorkommen von Paenibacillus larvae subsp. larvae Sporen in belgischen Honigen. Die Amerikanische Faulbrut (AFB) ist eine für die Larven der Honigbiene tödliche Krankheit, die durch das Sporen erzeugende Bakterium Paenibacillus larvae subsp. larvae hervorgerufen wird. Der Nachweis von Sporen in Völkern ohne Symptome im Jahr 1999 stellte das scheinbar geringe Vorkommen von AFB in Belgien in Frage. Um einen Überblick zu bekommen, wurden 1328 Honigproben der Honigernte 1999 bakteriologisch überprüft. Von diesen waren 146 Proben $(11 \%)$ mit P. l. larvae Sporen kontaminiert (Tab. I). Der Befall schwankte zwischen nur einer einzelnen Bakterienkolonie auf der Platte bis zur vollständigen Überwucherung derselben. Um den Einfluss von in der Nähe auftretenden AFB-Fällen auf das Auftreten von Sporen im Honig abzuschätzen, definierten wir ein Ausbruchsgebiet (OA; Abb. 1). Ein Ausbruchsgebiet ist eine Gruppe von Gebieten mit der jeweils gleichen Postleitzahl, die vollständig oder teilweise innerhalb eines $5 \mathrm{~km}$ Radius in dem zentralen Gebiet einer Postleitzahl liegen, in dem AFB in der Zeit von 1997-1999 nachgewiesen wurde. Eine statistische Analyse mit einer univariaten Regression mit SPSS 8.0 ergab 2 hoch signifikante Variable: ,innerhalb eines klinischen Befallsgebiet 1998“ und der „Häufigkeit innerhalb eines klinischen Befallsgebiet 1998“ (Tab. II). Demnach bestand ein erhöhtes Risiko P. l. larvae Sporen im Honig von Orten zu finden, die in der Nähe der Bienenstände mit klinischen Befunden der AFB lagen. Eine multifaktorielle Analyse von Daten der imkerlichen Praxis bei den entsprechenden Bienenständen zeigte, dass bereits ein Wabenaustausch zu einem nach der Wald Statistik signifikanten Ungleichverhältnis von 0,46 führte (Tab. III). Deshalb sollte ein häufiger Austausch von Waben bei der Völkerführung empfohlen werden, um die Bienenkrankheit durch Entfernung von befallenen Waben zu behandeln. Schließlich ergab sich noch eine signifikante Beziehung zwischen den Honigproben von 1999 mit positivem Sporenbefall (P. l. larvae $>0$ und > 10) und den AFB Fällen von 2000 (Ungleichverhältnis 2,64 bzw. 3,58; Tab. IV). Dies zeigt den Wert der Honiganalysen für die Gesundheitskontrolle von Bienenvölkern.

Paenibacillus larvae subsp. larvae / Amerikanische Faulbrut / Honig / Risikofaktorenanalyse 


\section{REFERENCES}

Alippi A.M. (1995) Detection of Bacillus larvae spore in Argentinian honeys by using a semi-selective medium, Microbiologia 11, 343-350.

Bailey L., Ball B.V. (1991) Honey bee pathology, Academic Press, London.

Dingman D.W., Stahly D.P. (1983) Medium promoting sporulation of Bacillus larvae and metabolism of medium components, Appl. Environ. Microbiol. $46,860-869$.

Dobbelaere W., de Graaf D.C., Peeters J.E., Jacobs F.J. (2001) Development of a fast and reliable diagnostic method for American foulbrood disease (Paenibacillus larvae subsp. larvae) using a $16 \mathrm{~S}$ rRNA gene based PCR, Apidologie 32, 363-370.

Fries I. (1988) Comb replacement and Nosema disease (Nosema apis Z.) in honey bee colonies, Apidologie 19, 343-354.

Goodwin M.R., Perry J.H., Ten Houten A. (1994) The effect of drifting honey bees on the spread of American foulbrood infections, J. Apic. Res. 33, 209-212.

Govan V.A., Allsopp M.H., Davison S. (1999) A PCR detection method for rapid identification of Paenibacillus larvae, Appl. Environ. Microbiol. 65, 2243-2245.

Hansen H. (1984) Methods for determining the presence of the foulbrood bacterium Bacillus larvae in honey, Tidsskr. Planteavl. 88, 325-328.

Hansen H., Brødsgaard C.J. (1999) American foulbrood: a review of its biology, diagnosis and control, Bee World 80, 5-23.

Hansen H., Rasmussen B. (1986) The investigation of honey from bee colonies for Bacillus larvae, Dan. J. Plant Soil Sci. 90, 81-86.
Heyndrickx M., Vandemeulebroecke K., Hoste B., Janssen P., Kersters K., De Vos P., Logan N.A., Ali N., Berkeley R.C.W. (1996) Reclassification of Paenibacillus (formerly Bacillus) pulvifaciens (Nakamura 1984) Ash et al. 1994, a later subjective synonym of Paenibacillus (formerly Bacillus) larvae (White 1906) Ash et al. 1994, as a subspecies of $P$. larvae, with emended descriptions of $P$. larvae as P. larvae subsp. larvae and P. larvae subsp. pulvifaciens, Int. J. Syst. Bacteriol. 46, 270-279.

Hitchcock J.D., Wilson W.T. (1973) Pathogenicity to honey bees of a strain of Bacillus larvae that does not reduce nitrate, J. Econ. Entomol. 66, 901-902.

Hornitzky M.A.Z., Clark S. (1991) Culture of Bacillus larvae from bulk honey samples for the detection of American foulbrood, J. Apic. Res. 30, 13-16.

Machova M. (1993) Resistance of Bacillus larvae in beeswax, Apidologie 24, 25-31.

Matheson A. (1984) Practical beekeeping in New Zealand, Government Printing Office, Wellington.

Ritter W. (1992) Examination of honey samples for diagnosis of Bacillus larvae, Apidologie 23, 361-363.

Sambrook J., Fritsch E.F., Maniatis T. (1989) Molecular cloning: a laboratory manual, Cold Spring Harbor Laboratory Press, Cold Spring Harbor.

Shimanuki H., Knox D.A. (1988) Improved method for the detection of Bacillus larvae spores in honey, Am. Bee J. 128, 353-354.

SPSS Inc. (1998) SPSS base 8.0 users guide package, Prentice Hall, New Jersey.

Steinkraus K.H., Morse R.A. (1992) American foulbrood incidence in some US and Canadian honeys, Apidologie 23, 497-501. 